Jurnal REKAN, Vol. 1, No 1, Maret 2020

\title{
PENGARUH SITEM AKUNTANSI KEUANGAN DAERAH, PEMANFAATAN TEKNOLOGI INFORMASI, KOMITMEN ORGANISASI TERHADAP KUALITAS INFORMASI LAPORAN KEUANGAN PEMERINTAH DAERAH KABUPATEN LOMBOK TENGAH
}

\author{
IKANG MURAPI \\ Akuntansi Universitas Bumigora Mataram \\ ikang.murapi11@universitasbumigora.ac.id
}

\begin{abstract}
Abstrak
Penelitian ini dilakukan untuk mengetahui faktor-faktor yang mempengaruhi kualitas informasi pada laporan keuangan pemerintah daerah. Penelitian ini bertujuan untuk menguji pengaruh langsung dari Penerapan Sistem Akuntansi Keuangan Daerah, Pemanfaatan Teknologi Informasi, Komitmen Organisasi terhadap Kualitas Informasi pada Laporan Keuangan Pemerintah Daerah. Populasi dalam penelitian ini adalah divisi akuntansi / administrasi keuangan SKPD di Kabupaten Lombok Tengah. Pendekatan pengambilan sampel untuk Tabachinick dan Fidell (2007). Sampel dipilih sebanyak 117 responden dari 39 SKPD dengan maksimal 3 responden di setiap SKPD di Kabupaten Lombok Tengah. Pengumpulan data dalam penelitian ini menggunakan survei kuesioner. Data yang dikumpulkan kemudian diproses menggunakan program SPSS versi 17.0. Metode statistik yang digunakan untuk menguji hipotesis adalah analisis regresi linier berganda.
\end{abstract}

Kata kunci: Kualitas Informasi Laporan Keuangan, Sistem Akuntansi Keuangan Daerah, Teknologi Informasi, Komitmen Organisasi

\section{PENDAHULUAN}

Laporan keuangan pemerintah daerah harus mengikuti Standar Akuntansi Pemerintahan (SAP) berbasis akrual yaitu Peraturan Pemerintah Nomor 71 Tahun 2010 sebagai pengganti PP No. 24 Tahun 2005.Kemudian laporan keuangan pemerintah disampaikan kepada DPRD dan masyarakat umum setelah diaudit oleh Badan Pemeriksa Keuangan(BPK). LKPD setiap tahunnya mendapat penilaian berupa Opini dari Badan Pengawas Keuangan (BPK). Opini yang diberikan atas suatu laporan keuangan merupakan cermin bagi kualitas pengelolaan dan penyajian suatu laporan keuangan.

Mengacu pada penelitian terdahulu penelitian ini merupakan penelitian pengembangan, bertujuan untuk menguji kembali penelitian yang dilakukan sebelumnya dan juga untuk memberikan pemahaman tentang faktor-faktor penting dalam menghasilkan kualitas Informasi Laporan Keuangan Pemerintah Daerah khususnya di Kabupatn Lombok Tengah. Dengan mempertimbangkan latar belakang dan penelitian-penelitian sebelumnya, maka penulis termotivasi melakukan penelitian ini untuk memperoleh bukti empiris tentang pengaruh, penerapan sistem akuntansi keuangan daerah (SAKD), pemanfaatan teknologi informasi, dan Komitmen Organisasi berpengaruh terhadap Kualitas Informasi Laporan Keuangan Pemerintah Daerah Kabupaten Lombok Tengah baik secara parsial maupun simultan?

KERANGKA PEMIKIRAN TEORITIS DAN PERUMUSAN HIPOTESIS 
Dalam sektor pemerintahan, masyarakat selaku principal memberikan amanat kepada pemerintah selaku agent untuk menyelenggarakan urusan pemerintahan dalam rangka meningkatkan kesejahteraan masyarakat (Hilmi dan Martani 2012). Dalam konteks teori signalling, pemerintah berusaha untuk memberikan sinyal yang baik kepada rakyat. Tujuannya agar rakyat dapat terus mendukung pemerintah yang saat ini berjalan sehingga pemerintahan dapat berjalan dengan baik. Laporan keuangan dapat dijadikan sarana untuk memberikan sinyal yang perlu diinformasikan kepada rakyat sebagai bentuk pertanggungjawaban (Verawaty, 2013). Berdasarkan telaah teoritis beberapa penelitian terdahulu, maka dikembangkan hipotesis penelitian pengaruh secara parsial dan pengaruh secara simultan dengan penjelasan sebagai berikut:

\section{Pengaruh Penerapan Sistem akuntansi Keuangan Daerah (SAKD) Terhadap Kualitas Informasi Laporan Keuangan Pemerintah Daerah}

Permadi (2013) dan Desianawati (2014) menyatakan Sistem Akuntasi Keuangan Daerah (SAKD) berperngaruh terhadap Kualitas Laporan Keuangan Pemerintah Daearah yang dihasilkan, hal itu dikarenakan dengan adanya Sistem Akuntansi Keuangan maka akan lebih mempermudah pemakai sistem akuntansi dalam mengolah data keuangan dan bekerja sesuai dengan standar akuntansi pemerintah yang sudah diterapakan sistem akuntansi keuangan tersebut, sehingga laporan keuangan yang dihasilkanpun akan memiliki kualitas yang baik. Berdasarkan penjelasan tersebut, hipotesis yang dapat dibangun adalah:

H1: Penerapan Sistem akuntansi Keuangan Daerah (SAKD) berpengaruh positif terhadap Kualitas Informasi Laporan Keuangan Pemerintah Daerah

\section{Pengaruh Pemanfaatan Teknologi Informasi Terhadap Kualitas Informasi Laporan Keuangan Pemerintah Daerah}

Desi dan Ertambang (2008), Celviana dan Rahmawati (2010). Darno (2012) berhasil menemukan bukti adanya pengaruh Pemanfaatan Teknologi Informasi Terhadap Kualitas Laporan barang kuasa pengguna. Berdasarkan penjelasan tersebut, hipotesis yang dapat dibangun adalah.

H2: Pemanfaatan Teknologi Informasi berpengaruh positif Terhadap Kualitas Informasi Laporan Keuangan Pemerintah Daerah.

\section{Pengaruh Komitmen Organisasi Terhadap Kualitas Informasi Laporan Keuangan Pemerintah Daerah}

Nugroho (2017), Lodhrakentjana (2013) dan Tuti Darmas (2008) Hasil penelitian ini konsisten dengan hasil penelitian sebelumnya yaitu menunjukan bahwa variabel Komitmen Organisasi Pemerintah berpengaruh positif dan signifikan pada kualitas informasi pelaporan keuangan. Berdasarkan penjelasan tersebut, hipotesis yang dapat dibangun adalah:

H3: Komitmen Organisasi Pemerintah berpengaruh positif Terhadap Kualitas Informasi Laporan Keuangan Pemerintah Daerah.

\section{METODE PENELITIAN}

\section{Jenis Penelitian}

Berdasarkan rumusan masalah, maka jenis penelitian ini tergolong pada penelitian asosiatif. Penelitian asosiatif / hubungan merupakan penelitian yang bertujuan untuk mengetahui hubungan dua variabel atau lebih (Sugiyono 2011:14). Hubungan yang digunakan dalam penelitian ini adalah hubungan kausal (causal effect) yaitu hubungan yang terjadi karena sebab akibat, yang menguji 
pengaruh Sistem Akuntansi Keuangan Daerah, Pemanfaatan Teknologi Informasi, dan Komitmen Organisasi sebagai variabel independen berpengaruh terhadap Kualitas Informasi Laporan Keuangan Pemerintah Kabupaten Lombok Tengah. Data penelitian ini adalah data primer yaitu data penelitian yang diperoleh atau dikumpulkan langsung dari sumber asli (tanpa perantara). Sedangkan sumber data primer dalam penelitian ini diperoleh dari jawaban atas kuesioner yang dibagikan kepada responden. Untuk mengukur pendapat responden digunakan lima point skala Likert.

\section{Populasi dan Sampel Penelitian}

Populasi dalam penelitian ini adalah bagian akuntansi/penatausahaan keuangan pada SKPD di Kabupaten Lombok Tengah. Pengambilan sampel menggunakan pendekatan Tabachinick dan Fidell (2007). Sampel terpilih sebanyak 117 reponden dari 39 SKPD dengan maksimal 3 responden ditiap SKPD di Kabupaten Lombok Tengah. Penentuan 3 responden pada tiap SKPD didasarkan pada asumsi bahwa persepsi Kasubag Keuangan, Bendahara Penerimaan/ Bendahara Pengeluaran/ Bendahara Umum yang mengetahui secara pasti mengenai pelaporan keuangan pada tiap SKPD.

\section{Definisi Operasional Variabel}

1) Variabel Terikat (Dependent Variable)

Variabel kualitas informasi laporan keuangan pemerintah daerah diukur dengan indicator yaitu : Aktivitas keuangan di masa lalu, ketepat waktuan penyajian, pengambilan keputusan, disajikan wajar dan jujur, informasi dapat dibandingkan, informasi dalam laporan keuangan dapat dipahami, sesuai SAP. Jumlah item pertanyaan adalah 9 item, diukur menggunakan skala Likert 1-5. Kriteria tersebut mengacu pada Peraturan Pemerintah Nomor 71 Tahum 2010 dan Bastian (2006), dan Armando (2013).

\section{2) Variabel Bebas (Independent Variable)}

Variabel penerapan sistem akuntansi keuangan daerah diukur dengan indikatoryaitu : Kesesuaian sistem dengan SAP, pengidentifikasian transaksi, pencatatan transaksi, bukti disetiap transaksi, pencatatan kronologis, pengklasifikasian transaksi, laporan keuangan setiap periode, pelaporanyang konsisten dan periodik. Jumlah itempertanyaan adalah 11 item, diuku rmenggunakan skala Likert 1-5. Kriteria tersebut mengacu pada penelitian yang dilakukan oleh Halim (2013), Permadi(2013), dan Desianawati (2014).

Variabel pemanfaatan teknologi informasi diukur dengan indikator yaitu: Sistem akuntansi sesuai SAP, jaringan internet, jaringan internet termanfaatkan dengan baik, aplikasi yang digunakan, laporan keuangan terkomputerisasi, software susuai dengan UU. Jumlah item pertanyaan adalah 10item, diukur menggunakan skala Likert 1-5. Kriteria tersebut mengacu pada Peraturan Pemerintah No. 56 Tahun 2005 dan penelitian yang dilakukan oleh Desi dan Ertambang (2008), Celviana dan Rahmawati (2010), dan Darno (2012).

Variabel Komitmen Organisasi diukur dengan indikator yaitu : Penerimaan terhadap tujuan organisas, keinginan untuk bekerja keras, hasrat untuk bertahan menjadi organisas, kewajiban moral, tindakan disiplin dan loyal. Jumlah item pertanyaan adalah 5 item, diukur menggunakan skala Likert 1-5. Kriteria tersebut mengacu pada penelitian yang dilakukan oleh Nugroho (2017), Lodhrakentjana (2013) dan Tuti Darmas (2008). Prosedur Analisis data Alat analisis yang digunakan dalam penelitian ini adalah analisis regresi linier berganda dengan program SPSS 17.

$$
\text { KILK }=\alpha+\beta 1 \text { SAKD }+\beta 2 \text { TI }+\beta 3 \text { KO + e }
$$

Dimana: 


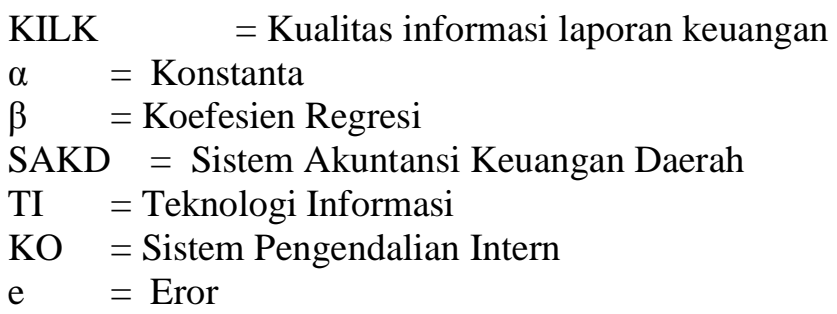

\section{HASIL DAN PEMBAHASAN \\ Deskripsi Data}

Data penelitian dikumpulkan dengan mengirimkan sebanyak 117 kuesioner yang diantar langsung ke 39 SKPD Kabupaten Lombok Tengah dengan responden sebanyak 117. Berikut tabel yang menunjukkan rincian pengiriman dan pengembalian kuesioner untuk masing-masing SKPD di Kabupaten Lombok Tengah. Tabel tersebut juga menginformasikan tingkat pengembalian kuesioner.

Tabel 1.

Penyebaran Kuesioner dan Informasi Tingkat Pengembaliannya

\begin{tabular}{lc}
\hline Keterangan & Jumlah \\
\hline Kuesioner yang dikirim & 117 \\
Kuesioner yang kembali & 97 \\
Kuesioner yang dapat digunakan & 97 \\
Kuesioner yang tidak digunakan (117-97) & 20 \\
Tingkat pengembalian kuesioner (97/117 x 100\%) & $83 \%$ \\
Tingkat pengembalian yang digunakan (97/117x & $83 \%$ \\
$100 \%)$ & \\
\hline
\end{tabular}

Sumber: Data primer diolah, 2015

Gambaran tentang karakteristik responden dalam penelitian meliputi umur, tingkat pendidikan, masa kerja, jenis kelamin dan status sebagai Kasubag Keuangan, Bendahara Penerimaan / Bendahara Pengeluaran / Bendahara Umum pada SKPD di Kabupaten Lombok Tengah.

Tabel 2.

Karakteristik Responden Berdasarkan Umur, Tingkat Pendidikan, Masa Kerja, Jens Kelamin, dan Status

\begin{tabular}{lcr}
\hline Keterangan & Jumlah Responden & Persentase \\
\hline Umur: & & \\
<30 tahun & 9 & 9.3 \\
31 - 40 Tahun & 53 & 54.6 \\
41 - 50 Tahun & 28 & 28.9 \\
>51 Tahun & 7 & 7.2 \\
\hline Tingkat Pendidikan: & 13 & \\
SMA & 11 & 13.4 \\
D3 & 69 & 11.3 \\
S1 & 4 & 71.1 \\
S2 & & 4.1 \\
\end{tabular}

Masa Kerja: 


\begin{tabular}{lcr}
\hline Keterangan & Jumlah Responden & Persentase \\
\hline$<5$ Tahun & 82 & 84.5 \\
6-10 Tahun & 12 & 12.4 \\
>11 Tahun & 3 & 3.1 \\
\hline Jenis & & \\
Kelamin: & & \\
Pria & 50 & 51.5 \\
Wanita & 47 & 48.5 \\
\hline Status: & & \\
Sudah & 94 & 96.9 \\
Menikah & & \\
Belum & 3 & \\
Menikah & & \\
\hline Sunber: Dat Diolah
\end{tabular}

Sumber : Data Diolah

\section{Hasil Uji Validitas}

Uji validitas digunakan untuk mengukur sah atau valid tidaknya suatu kuesioner (Ghozali, 2006:48). Uji validitas dapat dilakukan dengan menggunakan Korelasi Pearson (Pearson Correlation). Korelasi Pearson yaitu dengan menghitung korelasi antara skor masing-masing butir pertanyaan dengan total skor. Apabila nilai koefisien korelasi product moment $>r_{\text {Tabel }},(\alpha=n-2) n=$ jumlah sampel, maka dapat diambil kesimpulan bahwa item pernyataan/pertanyaan dalam kuisioner adalah valid, demikian juga sebaliknya jika koefisien korelasi $\mathrm{r}_{\text {hitung }}<\mathrm{r}_{\text {tabel }}$ maka dapat diambil kesimpulan bahwa item pernyataan/pertanyaan dalam kuisioner tersebut adalah tidak valid.

\section{Hasil Uji Reliabilitas}

Hasil uji reliabilitas menunjukkan bahwa semua item pertanyaan yang ada pada suatu kuesioner dapat dipercaya dan dapat digunakan sebagai alat pengumpul data. Suatu kuesioner yang reliabel apabila memberikan nilai Cronbach's Alpha > 0,60. Variabel sistem akuntansi keuangan daerah, pemanfaatan teknologi informasi, komitmen organisasi dan kualitas informasi laporan keuangan memiliki nilai Cronbach's Alpha > 0,60. Dengan demikian syarat reliabel alat ukur terpenuhi.

\section{1). Uji Normalitas}

Uji Normalitas dalam penelitian ini dilakukan dengan uji statistik non-prametrik KolmogorovSmirnov $(K-S)$. Pengujian dilakukan dengan menggunakan software program SPSS 17, dalam hal ini hasil uji normalitas diperoleh nilai Asymp. Sig. (2-tailed) sebesar 0,576. Hal ini berarti nilai Asymp. Sig. (2-tailed) lebih besar dari 0,05, dengan demikian dapat disimpulkan bahwa data mempunyai distribusi normal.

\section{2). Uji Multikolineritas}

Dari tabel diatas dapat dilihat bahwa semua variabel memiliki nilai tolerance $>0,1$ dan nilai Variance Inflation Factor $(V I F)<10$. Dengan demikian dapat disimpulkan bahwa tidak ada multikolinearitas antar variabel independen tersebut.

\section{3). Uji Heteroskedastisitas}

Berdasarkan hasil uji heteroskedastisitas dengan uji glejser menunjukkan bahwa tingkat signifikansi variabel sistem akuntansi keuangan daerah sebesar 0,633, pemanfaatan teknologi informasi sebesar 0,530, dan komitmen organisasi sebesar 0,799. Hal tersebut menunjukkan tingkat signifikansi keempat variabel lebih besar dari 0,05 , sehingga dapat disimpulkan tidak terjadi heteroskedastisitas dalam penelitian ini.

\section{Pengujian Hipotesis}


Analisis Regresi Linier Berganda

Setelah asumsi klasik terpenuhi maka tahap selanjutnya adalah melakukan uji analisis regresi linier berganda menggunakan program SPSS versi 17.

Tabel 3. Hasil Uji Regresi Linier Berganda

\begin{tabular}{|c|c|c|c|c|c|}
\hline Variabel & $\begin{array}{l}\text { Unstandardized } \\
\text { Coefficients (B) }\end{array}$ & $\begin{array}{l}\text { Std. } \\
\text { Error }\end{array}$ & $\mathrm{T}$ & Sig. & Keterangan \\
\hline (Constant & .844 & .208 & 4.053 & .000 & \\
\hline SAKD & .282 & .092 & 3.080 & .003 & Signifikan \\
\hline Pemanfaatan TI & .173 & .083 & 2.088 & .040 & Signifikan \\
\hline KO & .324 & .073 & 4.450 & .000 & Signifikan \\
\hline tod D Gau & $\begin{aligned} & =0,740 \\
e & =0,22726\end{aligned}$ & & & & \\
\hline
\end{tabular}

Sumber: Data diolah

Analisis Koefisien Determinasi (Uji Statistik R²)

Uji koefisien determinasi $\left(\mathrm{R}^{2}\right)$ adalah uji yang digunakan untuk mengetahui besaran dalam persen pengaruh variabel independen secara keseluruhan terhadap variabel dependen (Ghozali, 2006:83). Berdasarkan hasil uji koefisien determinasi pada tabel 4.17, diketahui nilai adjusted $R$ square ( koefisien determinasi yang telah disesuaikan) sebesar 0,740 . Nilai ini menunjukkan bahwa $74 \%$ variasi kualitas informasi laporan keuangan dapat dijelaskan oleh variasi dari semua variabel penerapan sistem akuntansi keuangan daerah, pemanfaatan teknologi informasi, dan Komitmen Organisasi pemerintah, sedangkan sisanya $26 \%$ dijelaskan oleh variabel lain yang tidak diikutkan dalam penelitian ini. Didalam perhitungan ini juga terdapat standar eror $(e)$ sebesar 0,22726 yang artinya kemungkinan kesalahan estimasi atau perhitungan dalam penelitian ini sebesar 0,22726.

Uji Signifikan Parameter Simultan (Uji Statistik F)

Dengan menggunakan program SPSS 17 didapat hasil uji F, berdasarkan hasil uji anova, didapat nilai $\mathrm{F}$ hitung sebesar 69.357 dengan probabilitas 0,000 . Karena probabilitas jauh lebih kecil dari 0,05 yang berarti semua variabel independen secara simultan mempengaruhi variabel kualitas informasi laporan keuangan, atau dapat dikatakan bahwa variabel penerapan sistem akuntansi keuangan daerah, pemanfaatan teknologi informasi, dan Komitmen Organisasi pemerintah secara bersama-sama berpengaruh terhadap kualitas informasi laporan keuangan Pemerintah Daerah Kabupatn Lombok Tengah.

Uji Signifikan Parameter Individual (Uji Statistik t)

Variabel penerapan sistem akuntansi keuangan daerah (X1) hasil yang signifikan positif dengan nilai $\mathrm{t}=3,080$ dengan tingkat signifikansi 0,003 . Hal ini bermakna bahwa secara signfikan, penerapan sistem akuntansi keuangan daerah berpengaruh positif terhadap kualitas informasi laporan keuangan. Variabel pemanfaatan teknologi informasi (X2) menunjukkan hasil yang signifikan positif dengan nilai $\mathrm{t}=2,088$ dan tingkat signifikansi 0,04 . Hal ini bermakna bahwa secara signfikan, pemanfaatan teknologi informasi berpengaruh positif terhadap kualitas informasi laporan keuangan. Selanjutnya variabel Komitmen Organisasi pemerintah (X3) menunjukkan hasil yang signifikan positif dengan nilai $\mathrm{t}=4,450$ dengan tingkat signifikansi 0,000 . Hal ini bermakna bahwa secara signfikan, Komitmen Organisasi pemerintah berpengaruh positif terhadap kualitas informasi laporan keuangan.

\section{Pengaruh penerapan sistem akuntansi keuangan daerah (SAKD) terhadap kualitas informasi laporan keuangan pemerintah daerah.}

Hipotesis kedua (H1) menyatakan bahwa penerapan sistem akuntansi keuangan daerah (SAKD) berpengaruh positif terhadap kualitas informasi laporan keuangan pemerintah daerah. Hasil regresi 
menunjukkan bahwa variabel penerapan sistem akuntansi keuangan daerah memiliki t hitung sebesar sebesar 3,080 dengan signifikansi 0,003 (lihat tabel 4.20). Nilai signifikansi 0,003 kurang dari derajat kepercayaan $(\alpha) 0,05$ sehingga hipotesis $\left(\mathrm{H}_{1}\right)$ diterima. Hasil penelitian ini sejalan dengan penelitian yang dilakukan oleh Permadi (2013) menyatakan Sistem Akuntasi Keuangan Daerah (SAKD) berperngaruh terhadap kualitas laporan keuangan. Desianawati (2014) hasil penelitian ini konsisten dengan hasil penelitian sebelumnya yaitu sistem akuntansi keuangan daerah berpengaruh positif dan signifikan terhadap kualitas laporan keuangan pemerintah daerah.

\section{Pengaruh pemanfaatan teknologi informasi terhadap kualitas informasi laporan keuangan pemerintah daerah.}

Hipotesis ketiga (H2) menyatakan bahwa variabel pemanfaatan teknologi informasi berpengaruh positif terhadap kualitas informasi laporan keuangan pemerintah daerah. Hasil regresi menunjukkan bahwa variabel pemanfaatan teknologi informasi memiliki t hitung sebesar sebesar 2,088 dengan signifikansi 0,040 (lihat tabel 4.19). Nilai signifikansi 0,04 kurang dari derajat kepercayaan $(\alpha) 0,05$ sehingga hipotesis $\left(\mathrm{H}_{2}\right)$ diterima. Hasil penelitian ini sejalan dengan penelitian yang dilakukan oleh Desi dan Ertambang (2008) yaitu pemanfataan teknologi informasi berpengaruh positif terhadap keterandalan pelaporan keuangan pemerintah daerah. Celviana dan Rahmawati (2010) menunjukkan bahwa pemanfaatan teknologi informasi berpengaruh positif signifikan terhadap keterandalan pelaporan keuangan pemerintah daerah.. Darno (2012) berhasil menemukan bukti adanya pengaruh pemanfaatan teknologi informasi terhadap kualitas laporan barang kuasa pengguna.

\section{Pengaruh Komitmen Organisasi Pemerintah Terhadap Kualitas Informasi Laporan Keuangan Pemerintah Daerah}

Hipotesis keempat (H3) menyatakan bahwa variabel Komitmen Organisasi pemerintah berpengaruh positif terhadap kualitas informasi laporan keuangan pemerintah daerah. Hasil regresi menunjukkan bahwa variabel pemanfaatan teknologi informasi memiliki t hitung sebesar sebesar 4,450 dengan signifikansi 0,000 (lihat tabel 4.19). Nilai signifikansi 0,000 kurang dari derajat kepercayaan $(\alpha) 0,05$ sehingga hipotesis $\left(\mathrm{H}_{3}\right)$ diterima. Hasil penelitian ini sejalan dengan penelitian yang dilakukan oleh Nugroho (2017) menyatakan bahwa Komitmen Organisasi Pemerintah berpengaruh positif terhadap kualitas informasi laporan keuangan pemerintah daerah. Lodhrakentjana (2013) terdapat pengaruh yang signifikan antara Komitmen Organisasi dengan kualitas informasi laporan keuangan pemerintah dan hubungannya positif. Hasil penelitian ini konsisten dengan hasil penelitian sebelumnya yaitu menunjukan bahwa variabel Komitmen Organisasi pemerintah berpengaruh positif dan signifikan pada kepuasan kerja Tuti Darmas (2008).

\section{Simpulan}

Dari hasil pengujian hipotesis dapat disimpulkan bahwa kualitas informasi laporan keuangan Pemerintah Daerah Kabupatn Lombok Tengah dipengaruhi oleh:

1) Pernyataan hipotesis kesatu (H1) dapat diterima, dengan demikian semakin diterapkan SAKD akan semakin baik prosedur penerapaan pelaporan keuangan pemerintah daerah, sehingga dalam rangka pertanggungjawabannya pelaksanaan APBD menjadi berkualitas. Sebaliknya dengan tidak diterapkan SAKD maka prosedur penerapan pelaporan keuangan pemerintah daerah dalam rangka pertanggungjawaban pelaksanaan APBD menjadi tidak berkualitas.

2) Pernyataan hipotesis kedua (H2) dapat diterima, semakin baik pemanfaatan teknologi informasi akan semakin cepat dan mudah pelayanan publik dapat diakses sehingga akan meningkatkan kualitas informasi laporan keuangan pemerintah daerah. Sebaliknya pemanfaatan teknologi informasi yang tidak baik menyebabkan pelayanan ke publik juga rendah sehingga informasi laporan keuangan menjadi tidak berkualitas.

3) Pernyataan hipotesis ketiga (H3) dapat diterima, hasil penelitian ini menunjukkan semakin tinggi penerapan komitmen organisasi, maka semakin tinggi pula pengaruhnya terhadap kualitas informasi laporan keuangan. 


\section{Saran Penelitian}

Berdasarkan hasil penelitian, pembahasan, kesimpulan dan keterbatasan pada penelitian ini, maka penulis dapat memberikan saran sebagai berikut:

1) Bagi SKPD Kabupaten Lombok Tengah

2) Dari hasil penelitian disarankan kepada pimpinan disetiap SKPD Kabupaten Lombok Tengah agar bisa meningkatkan kompetensi sumber daya manusia yang berkualitas dengan memberikan stimulus kepada staf bagian keuangan atau akuntansi supaya motivasi kerja terus ditingkatkan. Selain itu pentingnya komitmen organisasi akan memungkinkan seseorang bisa mengeluarkan sumber daya fisik, mental dan loyalitas yang tinggi dan kebanggaan. Jadi, dengan meningkatkan motivasi kerja dan komitmen organisasi, diharapkan tujuan pemerintah daerah dapat tercapai yaitu opini BPK Wajar Tanpa Pengecualian (WTP) terus dipertahankan ditahun-tahun berikutnya.

3) Bagi penelitian berikunya

a. Melengkapi penelitian selanjutnya dengan teknik obsevasi langsung serta menambah referensi-referensi terkait penelitian sejenis.

b. Selanjutnya dapat dilakukan perubahan variabel penelitian untuk menemukan variabelvariabel lain yang berpengaruh kuat terhadap kualitas informasi laporan keuangan yang dihasilkan oleh pemerintah seperti motivasi kerja dan variabel budaya organisasi.

\section{DAFTAR PUSTAKA}

Armando, Gerry. 2013. Pengaruh Sistim Pengendalian Itern Pemerintah dan Pengawasan Keuangan Daerah Terhadap Nilai Informsi Laporan Keuaangan Pemerintah (Studi Empiris pada Satuan Kerja Perangkat Daerah di Kota Bukittinggi). Program Studi Akuntansi: Universitas Negeri Padang.

Baja Lodhrakentjana1, Elvira Luthan.2013.Motivasi, Kepuasan Kerja, Komitmen Pegawai Akuntansi dan Kualitas Laporan Keuangan Pemerintah Daerah pada Pemerintah Kota Depok.Universitas Pancasila,Jakarta

Bastian, Indra. 2006. Akuntansi Untuk LSM dan Partai Politik. Penerbit Erlangga, Jakarta.

Adrianus Adhi Nugroho.2017. Pengaruh Motivasi Kerja dan Komitmen Organisasional Terhadap Kinerja Pegawai Studi pada Yayasan Budi Bakti Karya MASF Balikpapan Kalimatan Timur.Universitas Sanata dharma,Yogyakarta

Darmas Tuti Retno Puji. 2008.Pengaruh Motivasi Kerja dan Komitmen Organisasi Terhadap Kepuasan Kerja Auditor (Survei pada Auditor di KAP Wilayah Jateng dan DIY. Universitas Muhammadiyah, Surakarta

Darno. 2012. Analisis Pengaruh Kemampuan Sumber Daya Manusia Dan Pemanfaatan Teknologi Innformasi Terhadap Kualitas Laporan Barang Kuasa Pengguna (Studi pada Satuan Kerja di Wilayah Kerja KPPN Malang). Jurnal Ilmiah Mahasiswa FEB Universitas Brawijaya Malang. Vol. 1 No. 1

Desianawati, Kadek. 2014. Pengaruh Kompetensi SDM, Penerapan SAP, dan Sistim Akuntansi Keuangan Daerah Terhadap Kualitas Laporan Keuangan Pemerintah Daerah. e_Jurnal Akuntansi: Universitas Pendidikan Ganesha. Vol 2. No.1: 1-11

Forum Dosen Akuntansi Sektor Publik. 2006. Standar Akuntansi Pemerintahan: Telaah Kritis PP Nomor 24 Tahun 2004. BPFE, Yogyakarta.

Ghozali, Imam. 2006. Aplikasi Multivariate dengan Program SPSS, Edisi-3. Badan Penerbit. Universitas Diponegoro, Semarang.

Halim, Abdul. 2013. Akuntansi Sektor Publik: Akuntansi Keuangan Daerah, edisi-4. Salemba Empat, Jakarta.

Hevesi, G. Alan. 2005. Standards for Internal Control in New York State Government. www.osc.state.ny.us 
Hilmi, Amiruddin Z dan Dwi Martani. 2012. Analisis Faktor-faktor yang Mempengaruhi Tingkat Pengungkapan Laporan Keuangan Pemerintah Provinsi. Simposium Nasional Akuntansi XV Banjarmasin, 20-23 September 2012.

Indriasari, Desi dan Ertambang Nahartyo. 2008. Pengaruh Kapasitas Sumber Daya Manusia, Pemanfaatan Teknologi Informasi dan Pengendalian Intern Akuntansi Terhadap Nilai Informasi Pelaporan Keuangan Pemerintah Daerah (Studi pada Pemerintah Kota Palembang dan Kabupaten Ogan Illir). Kumpulan Simposium Nasional Akuntansi XI di Pontianak, 23-24 Juli.

Kusumadjaja, Levina. 2014. The Impact of Viral Marketing through Social Media on BCD's Consumer Brand Knowledge. iBuss Management Vol. 2, No. 2, (2014) 162-172. Jl. Siwalankerto 121131, Surabaya: International Business Management Program, Petra Christian University.

Mahaputra, I Putu Upabayu Rama. 2014. Analisis Faktor-Faktor Yang Mempengaruhi Kualitas Informasi Pelaporan Keuangan Pemerintah Daerah. Bali: e-Jurnal Fakultas Ekonomi dan Bisnis Universitas Udayana.

Mantauv, Citra Suci. 2013. Pengaruh Kepemimpinan, Linkungan Kerja, dan Motivasi Kerja Terhadap Kinerja Pegawai Pada Dinas Kebudayaan dan Pariwisata Kota Sawahlunto. e-Jurnal Apresiasi Ekonomi Volume 1 Nomor 2 Page 119-125, Publisher: LPPM STIE Pasaman Simpang Empat.

Mardiasmo. 2002. Akuntansi Sektor Publik Edisi Pertama. Yogyakarta: Penerbit Andi

Muhidin, Ali Sambas dan Abdurrahman Maman. 2007. Analisis Korelasi, Regresi dan Jalur Dalam Penelitian. Penerbit Pustaka Setia, Bandung.

Peraturan Menteri Dalam Negeri. Nomor 13 Tahun 2006. tentang Pedoman Pengelolaan Keuangan Daerah.

Peraturan Pemerintah Republik Indonesia. Nomor 56 Tahun 2005. tentang Sistim Informasi Keuangan Daerah.

Permadi, Angga Dwi. 2013. Pengaruh Penerapan Sistim Akuntansi Keuangan Pemerintah daerah Terhadap Kualitas Laporan Keuangan Pemerintah Daerah (Studi Kasus Pada Dinas Bina Marga Provinsi Jawa Barat). Univeritas Widyatama, Bandung.

Rora \& Dwi Martani. 2012. Analisis Pengaruh Kinerja dan Karakteristik Pemda Terhadap Tingkat Pengungkapan dan Kualitas Informasi dalam Website Pemda. Simposium Nasional Akuntansi XV Banjarmasin, 20-23 September 2012.

Sugiyono. 2011. Metode Penelitian Kuantitatif kualitatif dan R\&D. Alfabeta, Bandung.

Sukmaningrum, Tantriani. 2012. Analisis Faktor-Faktor Yang Mempengaruhi Kualitas Informasi Laporan Keuangan Pemerintah Daerah (Studi Empiris pada Pemerintah Kabupaten dan Kota Semarang). Graduate Thesis, Fakultas Ekonomika dan Bisnis: Universitas Diponegoro.

Tabachnick, B.G and Fiddel, L.S. 2007. Experimental Designs Using ANOVA. Belmont CA: Duxbury.

Triandis, H. C, 1980, "Values Attitude and Interpersonal Behavior” Nebraska

Trisnawati, Mya Dewi. 2014. Determinan Publikasi Laporan Keuangan Pemerintah Daerah Melalui Internet. SNA 17 Mataram Lombok.

Verawaty. 2013. Analisis Komparasi Indeks Internet Financial Reporting Pemerintah Daerah di Indonesia. Lembaga Penelitian Universitas Bina Darma, Palembang.

Wahyono, Teguh. 2004. Sistem Informasi (Konsep Dasar, Analisis, Desain dan Implementasi. Graha Ilmu, Yogyakarta.

Warisno, 2008, Faktor-Faktor yang Mempengaruhi Kinerja Satuan Kerja Perangkat Daerah (SKPD) di Longkungan Pemerintah Provinsi Jambi, Tesis, Sekolah Pascasarjana USU, Medan.

Winidyaningrum, Celviana dan Rahmawati. 2010. Pengaruh sumberdaya manusia dan pemanfaatan teknologi informasi terhadap keterandalan dan ketepatwaktuan pelaporan keuangan pemerintah daerah dengan variabel intervening pengendalian intern akuntansi. SNA 13: Universitas Jendral Soederman Purwokerto. 